\title{
Chalk Talk: Teaching Tips from the UGA Teaching Academy
}

\author{
Libby V. Morris
}

Published online: 1 December 2010

(C) Springer Science+Business Media, LLC 2010

Do you want to reinvigorate the conversation about teaching and learning on your campus? Do you want the campus to learn new and innovative teaching tips from colleagues while letting students get a glimpse into the instructional practices of leading teachers? Consider inviting faculty members on your campus to submit "tips on teaching." That's just what the Teaching Academy of the University of Georgia (UGA) did, and the buzz on campus is rather amazing. "Who is in the publication? What did they say?" One featured writer told me that her copy of the book is now missing, so perhaps I should write an editorial for a future issue on the ethics of "borrowing" and not returning books!

In fall 2009, the UGA Teaching Academy chose to celebrate the 10th anniversary of the Academy with a publication on teaching. The Academy is an honorary group that selects its own members and promotes teaching and learning on campus through workshops; speakers; and, importantly, by featuring an annual 3-day symposium on a topic important to the University community. Approximately 10 members are selected annually, based on nominations from academy members and others committed to teaching and learning. (The url below provides information on the Academy.)

This project was spearheaded by Loch Johnson, an inaugural member of the Academy and Regents Professor of Public and International Affairs, and Provost Jere Morehead, a Meigs teaching award winner and a member of the Teaching Academy. Provost Morehead provided the financial support for publishing the book. As a side note, the Meigs Distinguished Teaching Professorship is UGA's highest award for teaching and carries a permanent salary increase, which is quite a nice benefit in these tight economic times!

Professor Johnson invited the members of the Academy, which consists of over 100 faculty members, and the winners of the Russell and Meigs teaching awards to write essays of 1000 words or less explaining a particularly useful teaching practice. The deadline for submission was tight, less than 8 weeks. Amazingly, 69 faculty members accepted the invitation; and the result was Chalk Talk, a 192- page publication of thoughtful and innovative approaches to instruction used by UGA faculty from a wide range of schools and colleges.

L. V. Morris $(\bowtie)$

Institute of Higher Education, University of Georgia, 102 Meigs Hall, Athens, GA 30602-6772, USA

e-mail: lvmorris@uga.edu 
Catchy essay titles include "Toys for Teasing and Learning," "Three Chips and You are Out," and "The Button....Where's the Button." Essays came from faculty members in agriculture, business, law, arts and sciences, social work, veterinary medicine, education, engineering, and many other areas. Professor Johnson, who served as editor of the publication, explained his thoughts as follows:

I thought how wonderful it would be to tap into the experience of people here on campus. I know that, as an instructor myself, I always like to read about other people's techniques and hear about what really works for them in the classroom. I thought it would be a very practical way of being helpful to instructors. I especially had in mind the beginning assistant professor. Often times you get a Ph.D., and you never will have set foot in the classroom to do any teaching. Maybe you're a research assistant, but you never teach. So there you are-suddenly you're teaching your own classes, and you're clueless as to how to approach them. I thought it would be helpful if a beginning instructor had a guidebook based on the experiences of others. But I must say that a lot of senior faculty members tell me they've learned a lot by reading these essays, and I have, too. There are many wonderful gems here.

For example, Charles Bullock, Professor of Political Science, wrote an essay about arriving early for class and using this time to establish rapport with the students. He talks with them about career aspirations, aspects of the course, and any other topic that comes to mind. Over this informal talk, a bond develops between the students and the professor that might not exist otherwise. The topics of the essays are too many to summarize, but you can imagine the range. Chalk Talk, unlike some other books on teaching, does not subscribe to an overall teaching philosophy or method; it is a toolbox of useful practices or ideas borne out of experience and commitment to improvement. Ronald Simpson, former director of UGA's Institute of Higher Education and previous Editor of this journal, made this observation: "I taught for twenty years a course on college teaching to Ph.D. students from around the campus; and I came to learn that small, helpful teaching tips were usually more valuable than theory and philosophy."

If you would like to view UGA's Chalk Talk, you may do so at the University of Georgia's bookstore web site (see below). Of course, it can be ordered there, too. However, I think the greatest value is in creating a teaching tip book on your own, where you know the faculty members, could drop by their office for a chat about the essay, and even see a practice in action as part of a class. Chalk Talk celebrates teaching and teachers. It provides new faculty and experienced veterans a network of people willing to talk about teaching and dedicated to improving instruction. The authors in Innovative Higher Education fill every issue with useful ideas on teaching and learning and many other aspects of higher education; each would be an ideal contributor for chalk talk.

Best wishes in your quests to be innovative and effective in the classroom and beyond!

\section{Resources}

Josiah Meigs Distinguished Teaching Professorships. See: http://provost.uga.edu/index.php/resources/ awards/josiah-meigs-distinguished-teaching-professorships/

Richard Russell Undergraduate Teaching Awards. See http://provost.uga.edu/index.php/resources/awards/ richard-russell-undergraduate-teaching-awards/

Teaching Academy. See: http://www.uga.edu/teachingacademy/about.htm

UGA Bookstore, Chalk Talk. http://www.bkstr.com/ProductDisplay/10001-152754-102104000000000001124211-1?demoKey $=\mathrm{d}$ 